\title{
Tingkat dan Jenis Perubahan Fisik Ruang Dalam Pada Rumah Produktif (UBR) Perajin Tempe Kampung Sanan, Malang
}

\author{
Iwan Wibisono \\ Jurusan Arsitektur/Fakultas Teknik Universitas Brawijaya \\ iwanwibisono@ub.ac.id
}

\begin{abstract}
ABSTRAK
Rumah di Indonesia yang berangkat dari sistem religi dan budaya, memiliki fungsi dasar yang bertujuan untuk menjaga keharmonisan segala macam aktivitas yang berlangsung di dalamnya. Kesetimbangan dalam pengelolaan kegiatan rumah tangga dengan kegiatan produktif sangat diperlukan mengingat pengelolaan kedua kegiatan ini pada intinya sama, yaitu keluarga. Adanya fungsi produktif tersebut membawa dampak yang cukup signifikan terhadap pola tatanan ruang dalamnya. Keberadaan aktivitas produksi yang masuk ke dalam fungsi rumah hunian, maka akan menyebabkan terjadinya konsekuensi-konsekuensi tertentu yang dilakukan penghuni (dalam hal ini perajin tempe) pada ruang dalam rumahnya, apakah itu berupa penambahan jumlah ruang, luas ruang maupun perubahan pada material ruang (hunian dan produksi). Perubahan fisik ruang dalam rumah tersebut dapat dikategorikan ke dalam tiga tingkatan, yaitu perubahan ringan, sedang, maupun berat/total dibandingkan dari bentuk awal bangunan (ataupun dari fungsi rumah hunian jika memungkinkan). Masing-masing dari tingkat tersebut memiliki jenis perubahan yang berbeda. Untuk itu diperlukan identifikasi lebih lanjut tentang perubahan fisik ruang dalam apa saja yang terjadi akibat dari adanya fungsi produktif yang ada di dalam rumah hunian perajin tempe di Kampung Sanan. Setelah itu, kemudian peneliti berdasarkan variabel-variabel tertentu akan dapat dikelompokkan tingkat dan jenis perubahannya.
\end{abstract}

Kata Kunci: Rumah produktif, Tingkat dan Jenis, Perubahan fisik ruang dalam

\section{Pendahuluan}

Kampung Sanan terletak di Kelurahan Purwantoro, Kecamatan Blimbing. Kampung ini merupakan sentra produksi tempe khas Malang yang terbesar di Kota Malang. Kampung Sanan ini memiliki luas wilayah $\pm 32,47$ Ha dengan batas-batas wilayah, sebagai berikut:

- Sebelah utara : Sungai;

- Sebelah timur : Kelurahan Bunulrejo;

- Sebelah barat : : Jl. Raya Indragiri; dan

- Sebelah selatan : Jl. Bengawan Solo, Jl. Bango dan Jl. Lesti Utara.

Sentra industri perajin tempe di Kampung Sanan merupakan sentra Usaha Berbasis Rumah Tangga (UBR) terbesar di Kota Malang. Perubahan fisik yang cukup pesat akibat adanya UBR di rumah hunian masyarakat tidak dapat lagi dibendung, karena masyarakat berlombalomba ingin menjadikan rumahnya sebagai tempat perajin tempe. Salah satu kecenderungan perubahan fisik yang terjadi adalah pada ruang dalam rumah. Penelitian yang telah dilakukan sebelumnya oleh Tutuko (2004) dengan judul "Perkembangan Pola Hunian Rumah Produktif Kampung Sanan 'Tempe', Malang", telah membahas bagaimana perkembangan pola hunian secara makro dan mikro pada Kampung Sanan melalui pendekatan status-nilai-kendala (Silas, 1993). Hasil penelitian berupa gambaran pola perkembangan hunian secara makro (kawasan) dan mikro (rumah hunian) pada Kampung Sanan, Malang. Pada pola perkembangan rumah hunian (secara mikro), berdasarkan penggunaan ruang untuk kegiatan produktif dan domestik berdasarkan matriks frekuensi penggunaan ruang, ditemukan adanya tiga pola hunian. Berangkat dari hasil penelitian tersebut, peneliti ingin meneliti secara lebih spesifik lagi mengenai tingkat perubahan fisik ruang dalam yang terjadi pada rumah perajin tempe di Kampung Sanan. 
Hal yang mendasari dilakukannya penelitian tentang perubahan fisik ruang dalam adalah adanya fungsi produktif yang ada di dalam rumah hunian perajin tempe di Kampung Sanan. Hal ini dikarenakan ada dugaan bahwa adanya fungsi produktif tersebut membawa dampak yang cukup signifikan terhadap pola tatanan ruang dalamnya. Seperti kita ketahui bersama, bahwa dengan adanya aktivitas produksi yang masuk ke dalam fungsi rumah hunian, maka akan menyebabkan terjadinya konsekuensi-konsekuensi tertentu yang dilakukan penghuni (dalam hal ini perajin tempe) pada ruang dalam rumahnya, apakah itu berupa penambahan jumlah ruang, luas ruang maupun perubahan pada material ruang (hunian dan produksi).

Perubahan yang terjadi pada ruang dalam tersebut bermacam-macam, tergantung pada jenis kegiatan yang dilakukan perajin tempe. Untuk dapat mengamati lebih spesifik mengenai perubahan ruang dalam yang terjadi, maka peneliti mengkategorikan populasi pada jenis kegiatan yang dilakukan perajin tempe. Berdasarkan hal tersebut, didapatkan tiga kategori perubahan fisik ruang dalam yang terjadi pada rumah perajin tempe, yaitu (1) Rumah dengan fungsi perajin tempe mentah (2) Rumah dengan fungsi perajin keripik tempe (penggorengan); dan (3) Rumah dengan fungsi perajin tempe mentah dan keripik tempe.

Pada ketiga kategori di atas, terdapat dugaan bahwa pada masing-masing kategori mengalami perubahan fisik akibat dari adanya fungsi produktif yang ada di dalam rumah hunian perajin tempe di Kampung Sanan. Secara umum, perubahan fisik yang terjadi di Kampung Sanan dapat dibedakan menjadi dua, yaitu perubahan secara makro dan mikro. Perubahan secara makro mencakup keseluruhan tatanan ruang permukiman, sedangkan perubahan secara mikro lebih kepada perubahan yang terjadi pada ruang dalam rumah. Peneliti dalam hal ini lebih spesifik mencermati perubahan yang terjadi secara mikro, khususnya perubahan fisik ruang dalam yang terjadi di dalam rumah.

Perubahan fisik ruang dalam rumah tersebut diperkirakan akan dapat dikategorikan ke dalam tiga tingkatan, yaitu perubahan ringan, sedang, maupun berat/total dibandingkan dari bentuk awal bangunan (ataupun dari fungsi rumah hunian jika memungkinkan). Masing-masing dari tingkat tersebut memiliki jenis perubahan yang berbeda. Untuk itu diperlukan identifikasi lebih lanjut tentang perubahan fisik ruang dalam apa saja yang terjadi akibat dari adanya fungsi produktif yang ada di dalam rumah hunian perajin tempe di Kampung Sanan. Setelah itu, kemudian peneliti berdasarkan variabel-variabel tertentu akan dapat dikelompokkan tingkat perubahannya.

\section{Bahan dan Metode}

\subsection{Rumah Produktif: Usaha Berbasis Rumah Tangga (UBR)}

Menurut Home Based Enterprises (HBEs) (2002), karakteristik HBEs adalah:

a. Ukuran dan ruang Kerja; sejumlah besar hunian tidak mengalokasikan kegiatan HBEs pada ruang terpisah,

b. Frekuensi dan distribusi setiap tipe dari HBE memiliki kondisi pasar sendiri, memerlukan pemberian sumberdaya, dan berbaur dalam kondisi yang kompetitif,

c. Profitabilitas; pendapatan dari HBE didukung oleh pendapatan yang lain,

d. Kondisi pekerjaan; pekerjaan dilakukan sendiri karena mereka tidak mempunyai pekerja yang resmi,

e. Pekerja/pelaku; dalam HBE cenderung tergantung ada tidaknya pekerja tambahan dan bebas dalam menghitung jumlah pekerja.

Lipton dalam Tutuko (2004) menyebutkan beberapa karakteristik UBR, antara lain:

a. Keluarga mengontrol sebagian besar dari modal dan melibatkan diri bekerja;

b. Sebagian besar dari lahan, modal dan kerja milik keluarga ikut dilibatkan; dan

c. Kebanyakan dari kerja UBR dilakukan oleh keluarga.

Kemudian menurut Silas (2000), ada lima ciri pokok UBR, yaitu sebagai berikut:

a. Rumah dan rumah tangga menjadi modal dan basis dari kegiatan ekonomi keluarga;

b. Keluarga menjadi kekuatan pokok dalam penyelenggaraan UBR, mulai dari menyiapkan, menjalankan hingga mengendalikan semua kegiatan, sarana dan prasarana yang terlibat; 
c. Dasar dan pola kerja UBR terkait dengan dan menjadi bagian dari penyelenggaraan kerumahtanggaan. Istri/Ibu dan anak menjadi tulang pungguna dari penyelenggaraan UBR;

d. Rumah makin jelas merupakan proses yang selalu menyesuaikan diri dengan konteks kegiatan yang berlaku, termasuk kegiatan melakukan berbagai bentuk UBR; dan

e. Berbagai konflik yang timbul sebagai konsekuensi dari adanya UBR di rumah dapat diatasi secara alami, baik internal rumah maupun dengan lingkungan dan tetangga di sekitarnya yang terlibat langsung atau tidak langsung dalam berbagai kegiatan UBR.

Menurut International Home Based Enterprises (HBEs) Research (2002), dapat disimpulkan beberapa karakteristik UBR di Indonesia ditinjau dari aspek kepemilikan, ruang dalam serta materialnya, yaitu sebagai berikut:

a. Kepemilikan dari lahan dan rumah sebagian besar merupakan hak milik pribadi $(81,6 \%)$, hanya beberapa saja yang menyewa dari pemilik sebelumnya (Tabel 1.). Dengan status kepemilikan seperti ini, maka kecenderungan akan terjadi perubahan pada rumah sangatlah besar. Penghuni akan lebih rela untuk melakukan perubahan/perawatan/renovasi pada rumahnya sendiri, daripada mereka melakukan pada rumah yang mereka sewa.

Tabel 1. Tenure of Households with HBEs (Percentage)

\begin{tabular}{|l|c|c|c|c|}
\hline & Bolivia & India & Indonesia & South Africa \\
\hline Owns & 67,9 & 92 & 81,6 & 42,2 \\
\hline Owns through antecretico & 5,5 & 0 & 0 & 0 \\
\hline Owns (illegally occupying land) & 0 & 0 & 0 & 43,5 \\
\hline Rents from absent owner & 14,5 & 6 & 17,1 & 0 \\
\hline Rents from resident owner & 2,4 & 2 & 0,7 & 0 \\
\hline Others & 9,7 & 0 & 0,7 & 14,3 \\
\hline
\end{tabular}

Sumber: International Home Based Enterprises (HBEs) Research (2002)

b. Tipe rumah dengan adanya UBR sebagian besar merupakan rumah yang telah permanen, yaitu terbuat dari batu bata $(91,4 \%)$ (Tabel 2.). Hanya sebagian kecil saja yang masih bersifat semi-permanen $(8,6 \%)$. Hal ini membawa indikasi bahwa perubahan yang dilakukan sebagian besar lebih kepada aspek material.

Tabel 2. Type of Dwelling with HBEs (Percentage)

\begin{tabular}{|l|c|c|c|c|}
\hline & Bolivia & India & Indonesia & $\begin{array}{c}\text { South } \\
\text { Africa }\end{array}$ \\
\hline Brick, block, adobe, permanent & 100 & 63,3 & 91,4 & 21,9 \\
\hline Semi-permanent & 0 & 30 & 8,6 & 0 \\
\hline Wood, tin, Temporary & 0 & 6,7 & 0 & 78,1 \\
\hline
\end{tabular}

Sumber: International Home Based Enterprises (HBEs) Research (2002)

c. Material pada dinding bangunan UBR sebagian besar sudah menggunakan batu bata $(79,6 \%)$, sedangkan sebagian kecil masih menggunakan kayu/sesek $(1,3 \%)$. Sebanyak $19,1 \%$ rumah juga telah menggunakan bahan dinding berupa bata yang telah diplester (Tabel 3.).

Tabel 3. Building Materials Used In The Walls of Main Building (Percentage)

\begin{tabular}{|l|c|c|c|c|}
\hline & Bolivia & India & Indonesia & South Africa \\
\hline Plastic/cardboard/tarpaulin & 0 & 0 & 0 & 1,4 \\
\hline Wood & 0 & 6,7 & 1,3 & 0 \\
\hline Corrugated and other metal & 0 & 0 & 0 & 72,7 \\
\hline Adobe or mud brick & 57,3 & 0 & 0 & 0 \\
\hline Brick & 34,8 & 25,3 & 79,6 & 6,5 \\
\hline
\end{tabular}




\begin{tabular}{|l|c|c|c|c|}
\hline Brick and cement or plaster & 7,3 & 68 & 19,1 & 6,5 \\
\hline Cement blocks/concrete & 0,6 & 0 & 0 & 12,9 \\
\hline
\end{tabular}

Sumber: International Home Based Enterprises (HBEs) Research (2002)

d. Penggunaan ruang khusus untuk proses produksi pada rumah UBR di Indonesia masih jarang ditemui. Sebagian besar rumah hanya memiliki satu buah ruang khusus untuk proses produksi $(46,7 \%)$, sedangkan sebagian besar lagi tidak memiliki ruang khusus untuk proses produksi $(44,7 \%)$. Mereka menggunakan hampir seluruh ruang dalam yang ada pada rumah mereka untuk kegiatan produksi (Tabel 4.).

Tabel 4. Number of Rooms in The Main House Used for HBE (Percentage)

\begin{tabular}{|c|c|c|c|c|}
\hline & Bolivia & India & Indonesia & South Africa \\
\hline 0 & 34,5 & 68 & 44,7 & 87,8 \\
\hline 1 & 52,7 & 31,4 & 46,7 & 9,5 \\
\hline 2 & 10,3 & 0,7 & 8,6 & 2,7 \\
\hline 3 & 1,2 & - & - & - \\
\hline $4+$ & 1,2 & - & - & - \\
\hline
\end{tabular}

Sumber: International Home Based Enterprises (HBEs) Research (2002)

Hasil penelitian yang dilakukan Kusumawati (2003), mengemukakan bahwa permukiman dengan Usaha Berbasis Rumah Tangga dalam konteks permukiman kota di Malang mempunyai potensi sebagai berikut:

a. Rumah dan rumah tangga sebagai modal kerja;

b. Kampung memberi kesempatan dan kemudahan kerja mengingat lokasinya yang strategis terhadap sistem kota;

c. Komunalisme kehidupan masyarakat kampung memberi kekuatan untuk saling memberikan dukungan dan memudahkan kerja;

d. Tenaga tambahan yang setiap saat diperlukan di luar tenaga keluarga dengan mudah dapat diperoleh dari tetangga sekitarnya;

e. Melakukan proses pemberdayaan melalui proses saling membantu dan saling mengajarkan keahlian yang diperlukan;

f. Ada kelonggaran dalam banyak hal untuk melakukan UBR, termasuk masalah perizinan, pungutan, dan sebagainya, yang meringankan biaya kerja; dan

g. Menjadi basis bagi kekuatan kota yang bertumpu pada masyarakat dengan segala kelebihan dan kekurangannya.

\section{2. Tingkat perubahan pada ruang dalam rumah UBR}

Proses perubahan rumah bisa dlihat dari dua cara pandang, yaitu proses transformasi dan proses perbaikan rumah. Proses transformasi rumah melalui tiga proses, yaitu sebagai berikut (Turner dalam Tutuko, 2004):

a. Ekspansi/tumbuh, artinya mengadakan perluasan keluar;

b. Sub divisi, artinya mengadakan perbanyakan ruang melalui pembagian di dalam, misalnya membuat dinding penyekat ruang; dan

c. Penyempurnaan, artinya perubahan berkaitan dengan peningkatan kenyamanan, seperti penggantian bahan.

Proses perbaikan rumah itu sendiri dapat melalui (Turner dalam Tutuko, 2004b):

a. Perombakan rumah, artinya perubahan struktur fisik rumah secara total (bentuk, bahan, jumlah ruang dan ukuran ruang);

b. Penggantian bahan secara menyeluruh (lantai, dinding dan atap), tanpa mengubah jenis dan jumlah elemen rumah, luas rumah, jumlah ruang dan bentuk rumah/ruang; dan

c. Penggantian bahan pada sebagian elemen rumah, tanpa mengubah jenis dan jumlah elemen rumah, luas rumah, jumlah ruang dan bentuk rumah/ruang. 
International Research on Home Based Enterprises 2002 menyatakan bahwa terdapat efek HBEs pada ruang tempat tinggal. Hal ini dipengaruhi oleh empat faktor, yaitu sebagai berikut: a. Karakteristik hunian

1) Tipe Hunian, antara lain: tipe rumah dan material bangunan dinding;

2) Lokasi, antara lain: jalan utama, sudut jalan, dan kombinasi; dan

3) Kepemilikan, antara lain: pribadi, kepemilikan melalui orang lain, berada di tanah yang ilegal, menyewa dari orang yang tidak jelas, menyewa dari pemilik rumah, atau yang lain.

b. Ruang yang tersedia dalam tempat tinggal

1) Jumlah ruangan;

2) Area ruangan dalam rumah;

3) Dasar Kepemilikan; dan

4) Ruang per-orang.

c. Penggunaan tempat tinggal untuk HBEs

1) Konfigurasi ruang;

2) Jumlah ruangan dan ruang yang digunakan HBEs ;

3) Efek HBEs pada ruang domestik;

4) Frekuensi penggunaan ruang;

5) Pembagian dan pemisahan ruang; dan

6) Konflik dan masalah.

d. Perbaikan hunian

1) Alasan untuk perluasan dan perbaikan ruang;

2) Memindahkan perabot; dan

3) Penggunaan ruang di luar rumah.

Menurut Zeisel dalam Wicaksono (2005), aspek-aspek fisik yang perlu dicari perubahannya adalah:

a. By product of use

Ini merupakan pencarian jejak/sisa/ hasil sampingan suatu kegunaan terhadap fisik lingkungan. Jejak jejak tersebut merupakan pencerminan tentang apa yang telah mereka perbuat untuk kondisi sernacam itu, dan yang termasuk kelompok ini adalah erotions dan leftover.

b. Adaptations for use

Adaptasi ini menunjukkan perubahan-perubahan yang dilakukan oleh pemakai dengan membuat lingkungannya sedemikian rupa, sehingga sesuai dengan yang diinginkannya, dan yang termasuk adaptasi ini adalah:

1) Prop atau Tambahan-tambahan yang memang diperlukan. Tambahan ini mungkin atau karena terabaikan sebelumnya atau fisik yang lama dipandang tidak memberikan sesuatu seperti yang diinginkannya.

2) Tambahan yang sifatnya memudahkan, melarang, mencegah (separations). Hal ini menandakan adanya akibat sampingan terhadap rancangan fisik yang dikehendaki.

c. Displays of self

lni membantu pihak luar untuk mengelompokkan ke dalam lingkungannya sesuai dengan identitasnya. Displays of self ini terdiri dari personalisasi (unsur fisik yang dipakai untuk menunjukkan keunikannya atau individualitasnya) dan identifikasi (unsur yang dipakai untuk memudahkan pengenalan, identifikasi). Displays of self ini merupakan simbolisasi untuk menunjukkan siapa dirinya kepada orang lain.

d. Public messages

Hampir sama dengan display of self, perbedaannya bahwa sasaran yang dituju oleh public messages ini lebih luas dan lingkungannya lebih besar. Pesan-pesan atau simbol yang disampaikan lebih membawa nama kelompok daripada perseorangan.

International Home Based Enterprises (HBEs) Research (2002), menyatakan bahwa perubahan fisik yang terjadi pada Usaha Berbasis Rumah Tangga (UBR) di Indonesia mencakup hampir semua bagian dalam rumah. Perubahan-perubahan tersebut terjadi pada jumlah ruang, luas ruang maupun material ruang (ceiling, wall,floor, etc). Jenis perubahan 
serta prosentase jumlah perubahan fisik yang terjadi pada Usaha Berbasis Rumah Tangga (UBR) di Indonesia dapat dilihat pada tabel 2.6.

Tabel 5. Improvements Made Specifically for The HBE (Percentage Frequencies)

\begin{tabular}{|l|c|c|c|c|}
\hline & Bolivia & India & Indonesia & South Africa \\
\hline Shelter without walls joined to house & 0,6 & - & 2 & 3,6 \\
\hline Shelter without walls, freestanding & 0,6 & - & 0,7 & 0,7 \\
\hline Shelter with walls, freestanding & - & - & 0,7 & 2,9 \\
\hline Enclosure without roof & - & - & 0,7 & 0 \\
\hline New room(s) in the dwelling & 1,8 & 6 & 7,9 & 0 \\
\hline Change external wall(s) & - & - & 5,9 & 0,7 \\
\hline Change internal wall(s) & - & 4 & 3,9 & 0,7 \\
\hline Change ceiling(s) & - & 8 & 2,6 & 0,7 \\
\hline Improved floor(s) & - & - & 4,6 & 1,4 \\
\hline New doorway(s) & - & 11,3 & 3,9 & 0,7 \\
\hline New/larger window(s) & - & 8,7 & 2,6 & 0,7 \\
\hline Shelves/cupboards & - & 11,3 & 3,3 & 5,8 \\
\hline Others & 1,2 & 30 & 3,3 & 4,3 \\
\hline
\end{tabular}

Sumber: International Home Based Enterprises (HBEs) Research (2002)

Sardjono (2005), menyatakan bahwa ruang dalam pada sebuah bangunan rumah dapat dibedakan menjadi tiga fungsi, yaitu (1) Ruang publik; (2) Ruang privat; dan (3) Ruang servis. Ruang publik berupa ruang tamu dan teras depan, untuk ruang privat berupa ruang keluarga, ruang makan dan ruang tidur, sedangkan yang termasuk ruang servis adalah dapur dan kamar mandi. Ketiga jenis ruang ini sangat erat kaitannya dan mutlak harus ada dalam sebuah rumah. Seiring dengan kondisi perekonomian penghuni yang semakin meningkat, maka tuntutan peran ruang-ruang dalam rumah juga akan semakin meningkat sejalan dengan peningkatan aktivitas yang terjadi di dalam rumah. Setiap penghuni pasti ingin masing-masing aktivitas yang mereka lakukan di dalam rumah dapat diwadahi oleh ruangan tersendiri. Akan tetapi, keadaan dan kondisi lahan yang sempit acapkali menjadikan rumah tidak mungkin lagi untuk dilakukan perluasan ruangan, sehingga diperlukan pola untuk menyiasati ruang dalam tersebut agar dapat tetap mewadahi berbagai fungsi aktivitas yang terjadi di dalam rumah. Perubahan ruang tersebut dapat dilakukan dengan pemilihan perabot serta penataan ruang yang efektif dan efisien.

\section{3. Metode}

Penelitian dilakukan di permukiman perajin tempe RW XIV, XV, dan XVI Kampung Sanan, Kelurahan Purwantoro, Kecamatan Blimbing, Malang. Waktu dilakukannya penelitian selama 6 bulan.

Untuk mendapatkan hasil penelitian guna menjawab rumusan masalah yang ada, maka digunakan jenis Penelitian Kasus (Case Study). Menurut Nasution dalam Wicaksono (2005), Case Study adalah bentuk penelitian yang mendalam tentang suatu aspek lingkungan sosial termasuk manusia di dalamnya. Jenis penelitian Case Study ini dapat digunakan untuk memberikan gambaran mengenai perkembangan yang terjadi pada suatu kasus sampai pada keadaan saat ini. Hasan (2002) menyatakan bahwa penelitian kasus adalah penelitian mengenai status subjek penelitian yang berkenaan dengan suatu fase spesifik atau khas dari keseluruhan personalitas. Hasil dari suatu penelitian kasus merupakan suatu generalisasi dari pola-pola kasus yang tipikal dari objek. Ruang lingkup studi dari penelitian kasus ini tergantung dari tujuan peneliti dapat mencakup segmen atau bagian tertentu atau mencakup keseluruhan siklus kehidupan objek dan sebagainya, baik dengan penekanan terhadap faktor-faktor khusus tertentu, maupun keseluruhan faktor-faktor dan fenomena yang terjadi. 
Data yang digunakan dalam penelitian (bahan penelitian) dapat berupa populasi (universe) atau sampel. Pengambilan sampel menggunakan teknik Stratified Purposive Random Sampling, yaitu pemilihan sampel diawali dengan pengklasifikasian/pengkategorian tertentu dari seluruh populasi, untuk kemudian dipilih secara acak disesuaikan dengan tujuan peneliti (jumlah sampel terlebih dahulu dihitung dengan menggunakan rumus Sloven).

Data-data yang telah diperoleh dari responden dengan bantuan metode-metode di atas, kemudian dikumpulkan, disajikan dalam bentuk tabel awal (ditabulasikan) untuk selanjutnya dilakukan analisis data. Analisis data adalah proses mengorganisasikan dan mengurutkan data ke dalam pola, kategori, dan satuan uraian dasar, sehingga dapat ditemukan tema dan dapat dirumuskan hipotesis kerja seperti yang disarankan oleh data (Moleong dalam Hasan, 2002).

Analisa data pada penelitian ini menggunakan metode analisa kuantitatif dan kualitatif. Metode kuantitatif digunakan hanya sebatas untuk menghitung jumlah maupun prosentase dari data yang didapatkan (ditabulasikan) untuk mempermudah dalam menghitung dan mengelompokkan data. Untuk selanjutnya analisa data dilanjutkan dengan metode kualitatif. Adapun metode kualitatif, yaitu analisa yang tidak menggunakan model matematik, model statistik dan ekonometrik atau model-model tertentu lainnya. Analisis data yang dilakukan secara kualitatif lebih menitik beratkan pada penganalisaan teknik pengolahan datanya, seperti pada pengecekan data dan tabulasi. Sumber data utama diperoleh dari survey primer dengan menggunakan metode pengamatan, wawancara dan kuisioner (serta bantuan berupa sketsa yang dilakukan oleh oleh peneliti berdasar pada informasi yang diberikan oleh responden). Data-data tersebut adalah data tentang perubahan fisik ruang dalam rumah perajin, serta faktorfaktor penyebabnya. Sampel yang diteliti juga dikategorikan menjadi tiga kategori, yaitu (1) Rumah dengan fungsi perajin tempementah; (2) Rumah dengan fungsi perajin keripik tempe (penggorengan); dan (3) Rumah dengan fungsi perajin tempe mentah dan keripik tempe. Sedangkan pada perubahan fisik ruang dalam sampel diklasifikasikan menjadi 3 kategori, yaitu (1) Perubahan kecil; (2) Perubahan sedang; dan (3) Perubahan besar.

\section{Hasil dan Pembahasan}

\subsection{Karakteristik ruang dalam rumah produktif}

Karakteristik bangunan dan ruang dalam rumah produktif perajin tempe di Kampung Sanan dapat disimpulkan sebagai berikut:

- Terdapat berbagai macam kategori jumlah ruang dalam pada rumah produktif berbasis UBR yang ada di Kampung Sanan. Mayoritas adalah rumah dengan jumlah ruang 5 dan 4 buah. Penggunaan ruang pada Rumah produktif berbasis UBR yang ada di Kampung Sanan, mayoritas digunakan untuk dua fungsi kegiatan, yaitu fungsi domestik dan fungsi produktif. Hampir semua ruang yang ada digunakan untuk kedua fungsi tersebut. Diantara ruangruang yang ada sebagian besar bahkan hampir semua ruang digunakan untuk proses produksi tempe. Dari 176 responden, sebanyak 4 responden sudah memiliki ruang toko tersendiri dan 20 responden sudah memiliki ruang produksi. Sedangkan untuk yang belum memiliki toko maupun ruang produksi sendiri, mayoritas menggunakan dapur saja sebagai ruang produksi, yaitu sebanyak 72 responden. Untuk yang lainnya menggunakan dapur dan berbagai ruang yang ada untuk proses produksi mereka, seperti teras, ruang tamu, ruang keluarga dan kamar mandi.

- Hanya terdapat satu ruang yang murni digunakan untuk fungsi domestik oleh seluruh penghuni. Mayoritas menganggap bahwa ruang tidur merupakan ruang yang tidak boleh digunakan untuk proses produksi. Mayoritas baik dari penghuni memiliki alasan bahwa ruang tersebut merupakan ruang privat. Ruang privat tersebut merupakan ruang yang khusus untuk fungsi domestik (rumah tangga) yang paling pribadi dan tidak untuk digunakan sebagai fungsi produktif.

\subsection{Karakteristik perubahan fisik ruang dalam pada rumah produktif}

Untuk dapat mengetahui tingkat perubahan, maka harus diketahui dulu jenis perubahan yang terjadi. Dari 149 penghuni yang pernah melakukan perubahan pada ruang dalam rumah 
mereka, sebanyak 24 penghuni pernah melakukan perubahan berupa penambahan jumlah lantai, luas lantai, plafond, dinding dan lantai. Sebanyak 27 penghuni telah melakukan perubahan pada lantai, plafond dan dinding. Sementara sisanya, sebanyak 98 penghuni melakukan perubahan pada plafond/dinding/lantai saja. Untuk lebih jelasnya dapat dilihat pada tabel 6 di bawah ini.

Tabel 6. Jenis Perubahan Pada Rumah Perajin Tempe Di RW XIV, XV, dan XVI, Kampung Sanan, Malang

\begin{tabular}{|c|c|c|}
\hline JENIS PERUBAHAN & JUMLAH & PROSENTASE (\%) \\
\hline Perubahan plafond & 36 & 24,2 \\
\hline Perubahan dinding & 30 & 20,1 \\
\hline Perubahan lantai & 32 & 21,5 \\
\hline $\begin{array}{c}\text { Perubahan jumlah, luas ruang, plafond, dinding dan } \\
\text { lantai }\end{array}$ & 27 & 18,1 \\
\hline JUMLAH & 24 & 16,1 \\
\hline
\end{tabular}

Sumber: Olahan data primer.

Dari tabel jenis perubahan di atas, maka dapat diketahui tingkat perubahan fisik ruang dalam pada rumah produktif perajin tempe di Kampung Sanan. Mengacu pada teori Housing as a Process (Turner dalam Supriyanto, 2000), maka peneliti dapat mengkategorikan tingkat perubahan fisik ruang dalam sebagai berikut: (a) perubahan kecil, apabila terjadi penggantian bahan pada sebagian elemen rumah, tanpa mengubah jenis dan jumlah elemen rumah, luas rumah, jumlah ruang dan bentuk rumah/ruang; (b) perubahan sedang, apabila terjadi penggantian bahan secara menyeluruh (lantai, dinding dan atap), tanpa mengubah jenis dan jumlah elemen rumah, luas rumah, jumlah ruang dan bentuk rumah/ruang; dan (c) perubahan besar, apabila terjadi perombakan rumah, artinya perubahan struktur fisik rumah secara total (bentuk, bahan, jumlah ruang dan ukuran ruang).

Untuk yang termasuk ke dalam kategori perubahan kecil terjadi pada 98 rumah, perubahan sedang terjadi pada 27 rumah, dan perubahan besar terjadi pada 24 rumah. Tingkat perubahan pada rumah perajin dapat dilihat pada tabel 7.

Tabel 7. Tingkat Perubahan Pada Rumah Perajin Tempe Di RW XIV, XV, dan XVI, Kampung Sanan, Malang

\begin{tabular}{|c|c|c|}
\hline TINGKAT PERUBAHAN & JUMLAH & PROSENTASE (\%) \\
\hline Perubahan kecil & 98 & 65,8 \\
\hline Perubahan sedang & 27 & 18,1 \\
\hline Perubahan besar & 24 & 16,1 \\
\hline JUMLAH & $\mathbf{1 4 9}$ & $\mathbf{1 0 0}$ \\
\hline
\end{tabular}

Sumber: Olahan data primer.

Jika lebih diuraikan pada tiap tingkat perubahan, maka untuk perubahan kecil yang terjadi pada 98 rumah perajin tempe sangat beragam. Perubahan kecil tersebut mencakup perubahan pada plafond, pada dinding atau pada lantai. Untuk perubahan pada plafond didominasi oleh perubahan dari rumah tanpa plafond menjadi asbes, yaitu sebanyak 29 rumah. Untuk perubahan pada dinding didominasi perubahan dari batu bata tanpa plester menjadi batu bata dengan plester, yaitu sebanyak 25 rumah. Pada perubahan lantai dominasi pada perubahan dari plester semen menjadi lantai keramik, sebanyak 18 rumah. 
Tabel 8. Perubahan Kecil Pada Rumah Perajin Tempe Di RW XIV, XV, dan XVI, Kampung Sanan, Malang

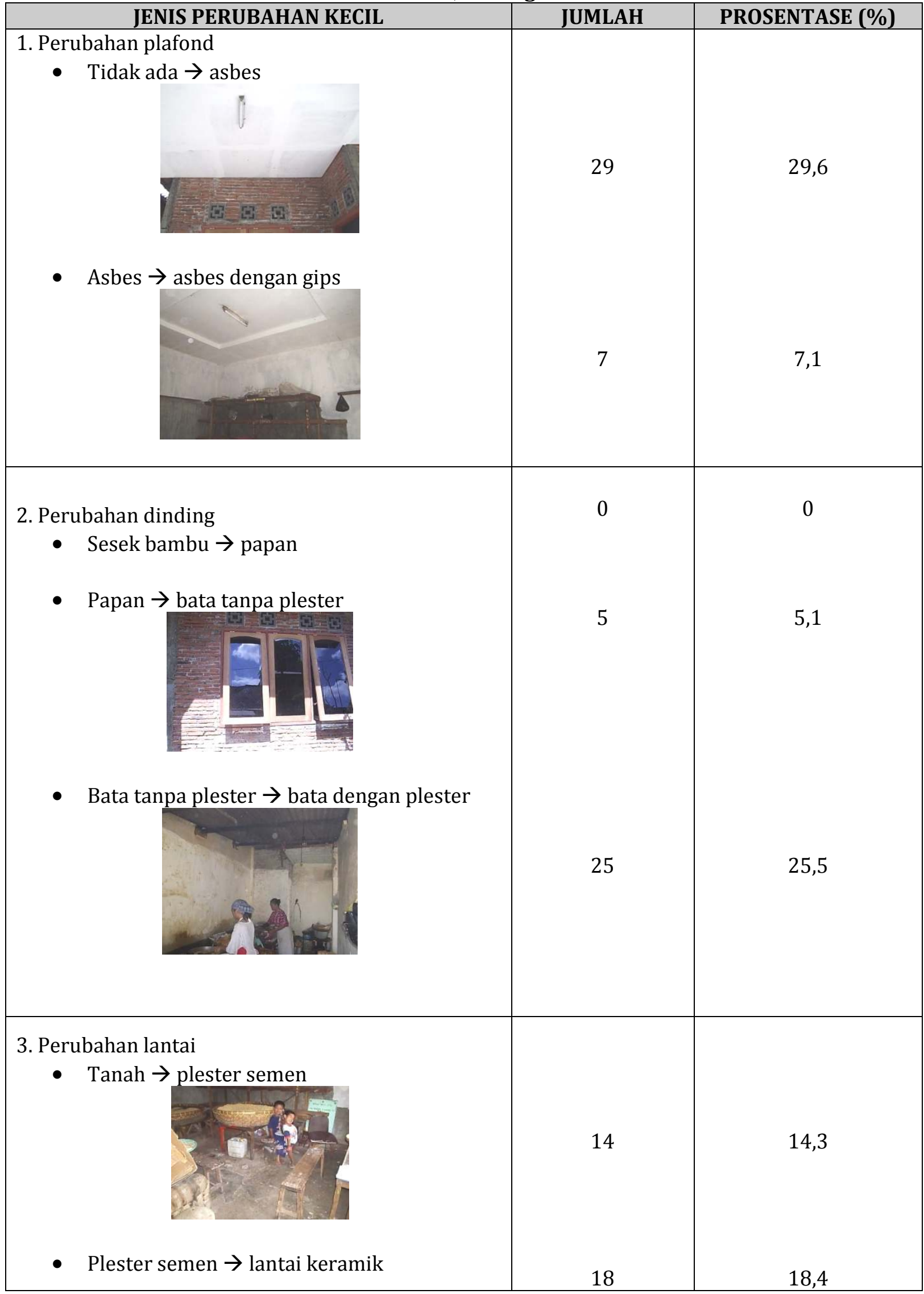




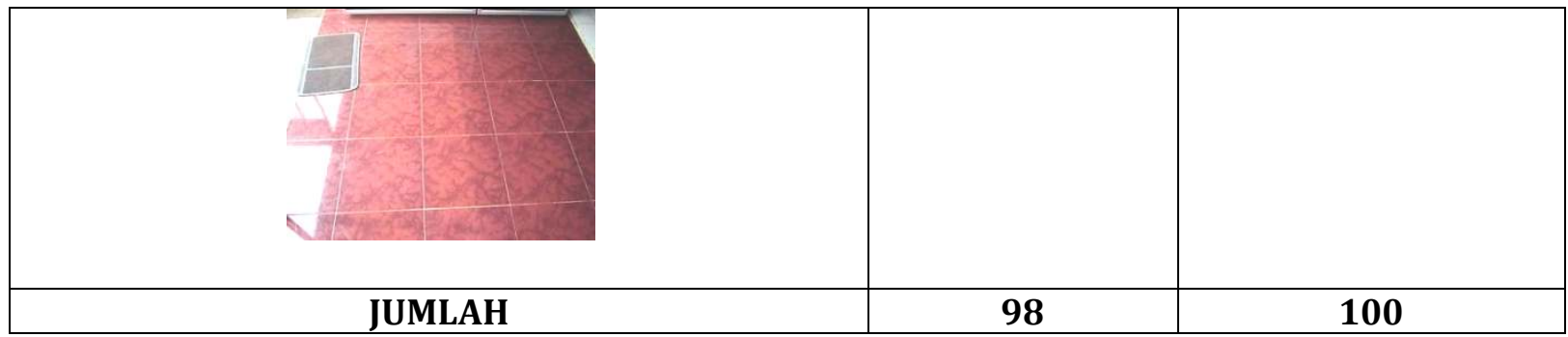

Sumber: Olahan data primer.

Pada perubahan sedang, dari 27 responden, didominasi oleh perubahan pada plafond dan lantai yaitu sebanyak 9 rumah. Perubahan sedang tidak lain adalah pengembangan dari tingkat perubahan kecil, namun dilakukan pada tidak pada satu elemen saja, melainkan pada beberapa elemen ruang dalam. Data selengkapnya dapat dilihat pada tabel 9.

Tabel 9. Perubahan Sedang Pada Rumah Perajin Tempe Di RW XIV, XV, dan XVI, Kampung Sanan, Malang

\begin{tabular}{|l|c|c|}
\hline JENIS PERUBAHAN SEDANG & JUMLAH & PROSENTASE (\%) \\
\hline • Perubahan plafond dan dinding & 7 & 25,9 \\
\hline - Perubahan plafond dan lantai & & \\
\hline - Perubahan plafond, dinding dan lantai & 9 & 33,4 \\
\hline & & \\
\hline \\
\hline
\end{tabular}


Sumber: Olahan data primer.

Pada perubahan besar, dari 24 responden, didominasi oleh perubahan berupa penambahan ruang produktif pada bagian balakang sebanyak 11 rumah. Hal tersebut merupakan cara yang paling banyak dilakukan penghuni yang melakukan perubahan besar. Ini dikarenakan luas lahan yang sangat terbatas, dan sebagian besar dari penghuni berusaha memanfaatkan letak dapur yang ada di belakang untuk dilakukan perubahan besar. Hal tersebut dilakukan karena dapur merupakan ruangan yang paling vital dalam rumah produktif perajin tempe di Kampung Sanan. Dengan adanya penambahan ruang produktif baru, biasanya dapur untuk fungsi domestik tetap dibiarkan ada, walaupun ukurannya kecil, karena penggunaannya tidak sebanyak ruang produksi. Untuk penambahan dan perluasan ruang ke arah depan mayoritas dilakukan oleh perajin keripik tempe (penggorengan) yang ada di RW XIV, hal tersebut berupa sebuah bangunan toko untuk fungsi pemasaran produk keripik tempe. Data jenis perubhan besar yang terjadi dapat dilihat pada tabel 10 .

Tabel 10. Perubahan Besar Pada Rumah Perajin Tempe Di RW XIV, XV, dan XVI, Kampung Sanan, Malang

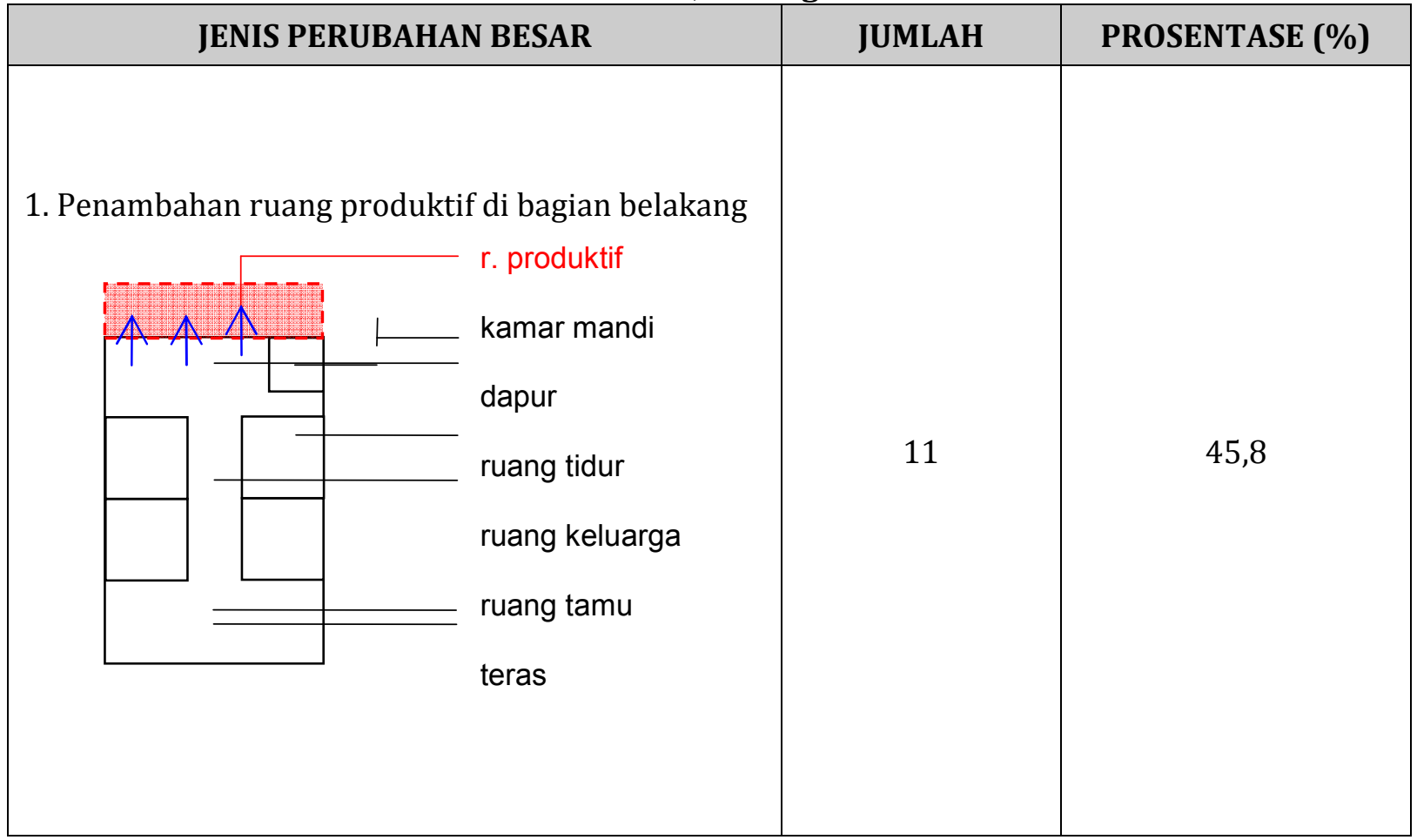




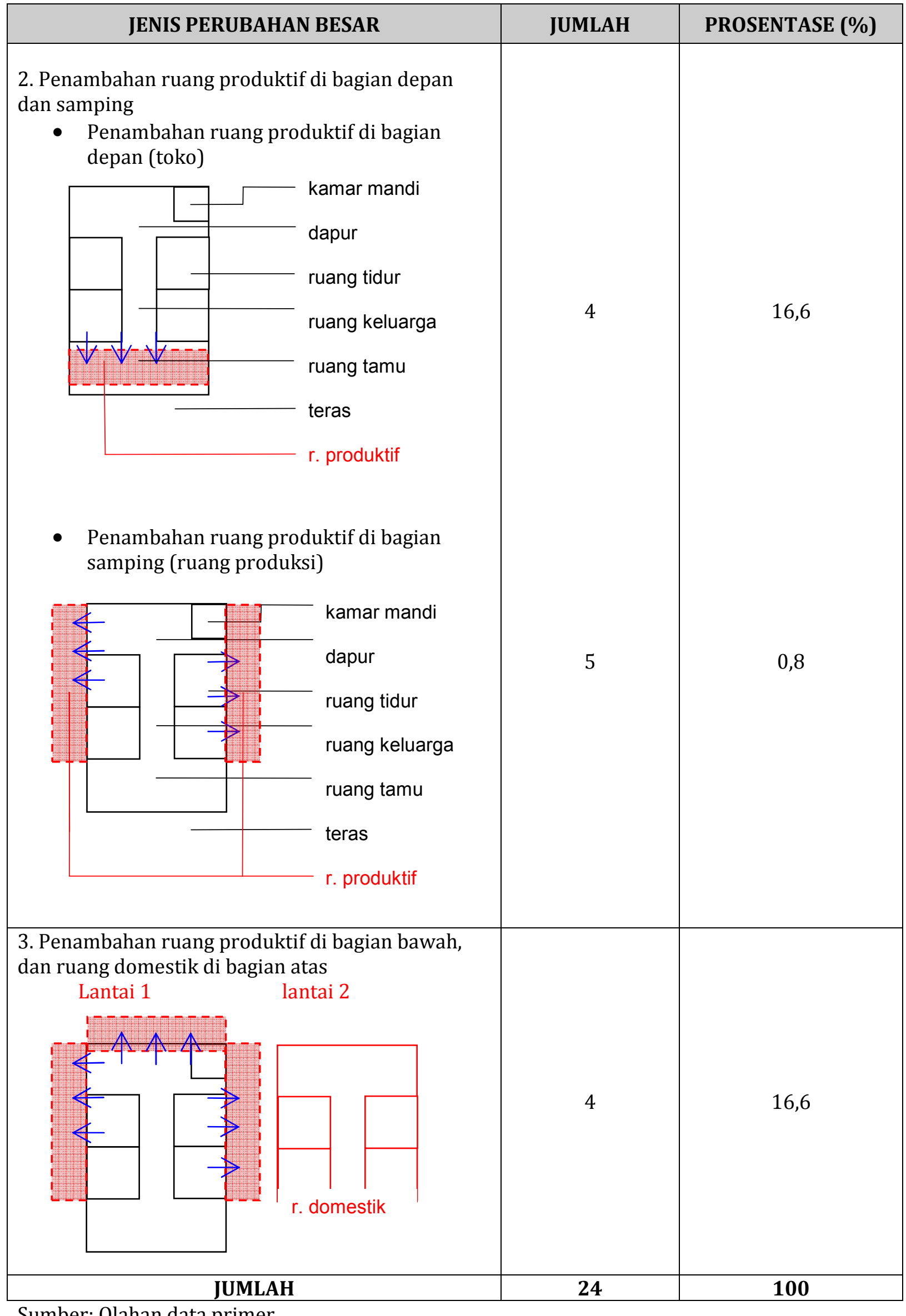

Sumber: Olahan data primer. 


\section{Kesimpulan}

- Mayoritas penghuni pernah melakukan perubahan fisik ruang dalam pada rumah mereka. Sebagian besar dari mereka pernah melakukan perubahan sebanyak satu kali. Hal tersebut menunjukkan bahwa masyarakat semakin sadar akan pentingnya kondisi rumah mereka demi menunjang kelangsungan usaha mereka, sehingga banyak perubahan fisik ruang dalam rumah yang dilakukan mulai saat itu. Karena bagaimanapun kelangsungan hidup sebagian besar dari perajin tergantung pada kelancaran usaha mereka.

- Untuk kategori jenis ruang yang pernah mengalami perubahan, mayoritas perubahan dilakukan pada dapur. Ini menunjukkan bahwa dapur merupakan ruang yang paling vital baik dalam menunjang fungsi domestik maupun fungsi produktif pada rumah produktif perajin tempe di Kampung Sanan. Akan tetapi, ruang-ruang lainnya juga tidak kalah pentingnya, karena sebagian besar ruang yang ada pada rumah produktif digunakan untuk dapat menjalankan dua fungsi sekaligus.

- Untuk dapat mengetahui tingkat perubahan, maka harus diketahui dulu jenis perubahan yang terjadi. Dari 149 penghuni yang pernah melakukan perubahan pada ruang dalam rumah mereka, sebanyak 24 penghuni pernah melakukan jenis perubahan berupa penambahan jumlah lantai, luas lantai, plafond, dinding dan lantai. Sebanyak 27 penghuni telah melakukan jenis perubahan pada lantai, plafond dan dinding. Sementara sisanya, sebanyak 98 penghuni melakukan jenis perubahan pada plafond/dinding/lantai saja.

- Dari tingkat perubahan di tersebut, maka dapat ditentukan bahwa tingkat perubahan kecil terjadi pada 98 rumah, perubahan sedang pada 27 rumah, dan perubahan besar pada 24 rumah.

\section{Daftar Pustaka}

\section{Jurnal dan Proceedings}

Aryanti, Dewi. Antariksa dan S. Soesanto. 2005. Pengaruh Kegiatan Berdagang Terhadap Pola Ruang Dalam Pada Bangunan Rumah-Toko di Kawasan Pecinan Kota Malang. Jurnal Teknik Arsitektur Dimensi, Universitas Kristen Petra Surabaya, Volume 33, Juli 2005.

Asikin, Damayanti, Galih W. P. dan Surjono 2000. Studi Pemakaian Ruang Privat Pada Ruang Hunian. Studi Kasus Desa Pengrajin Batu Alam di Gamping, Kabupaten Tulungagung. Jurnal Teknik, Volume VII No. 1 April 2000.

Septiani, Dewi. 2000. Rumah sebagai tempat tinggal dan tempat bekerja: Pola pemanfaatan ruang pada Usaha Rumah Tangga. Kelurahan Banyu Urip, Surabaya. Makalah disampaikan pada Seminar Rumah Produktif dalam Dimensi Tradisional dan Pemberdayaan dalam rangka Dies Natalis Arsitektur ITS ke-35, Institut Teknologi 10 November. Surabaya.

Setijani, Purwanita \& J. Silas. 2000. Considering The Concept Of Production Housing In Indonesia. The Cardo International Conference on Housing, Work and Development: The Role of Home-Based Enterprises. Henderson Hall. The University of Newcastle upon Tyne, UK 26-28 April 2000.

Silas, Johan. 1983. Beberapa Pemikiran Dasar Tentang Perumahan dan Perkampungan di Indonesia, Makalah dalam Diskusi Ilmiah Mahasiswa Arsitektur Indonesia di Bandung. Bandung, 29 September 1983.

Silas, Johan. 1993. Housing Beyond Home. The aspect of resource and sustainability. Pidato Pengukuhan Untuk Jabatan Guru Besar Teknik Arsitektur Fakultas Teknik Sipil dan Perencanaan, Institut Teknologi 10 November. Surabaya, 15 Mei 1993.

Silas, Johan. 1996. Padadoks Pengadaan Perumahan Kota,Majalah Analisis Sistem Edisi Khusus Tahun II, Kedeputian Bidang Analisis Sistem BPPT, Jakarta.

Silas, Johan. 2000. "Rumah Produktif, Pendekatan Tradisi dan Masyarakat". Makalah disampaikan pada Seminar Rumah Produktif dalam Dimensi Tradisional dan Pemberdayaan dalam rangka Dies Natalis Arsitektur ITS ke-35, Institut Teknologi 10 November. Surabaya. 
Supriyanto, Aries. 2000. Perubahan fisik rumah tinggal dengan adanya usaha yang bertumpu pada rumah tangga, di Kampung Sekarbela, Mataram. Makalah disampaikan pada Seminar Rumah Produktif dalam Dimensi Tradisional dan Pemberdayaan dalam rangka Dies Natalis Arsitektur ITS ke-35, Institut Teknologi 10 November. Surabaya.

Swanendri, Ni Made. 2000. The Existence Of Balinese House For Home Based Enterprises (HBEs) Activities. Case Study: Belega and Bona Village, Blahbatuh, Gianyar Regency, Bali. The Cardo International Conference on Housing, Work and Development: The Role of HomeBased Enterprises. Henderson Hall. The University of Newcastle upon Tyne, UK 26-28 April 2000.

Tutuko, Pindo. 2004. Inti Perkembangan Rumah Produktif Dalam Konsep Berkelanjutan. Studi Kasus Sentra Industri Tempe Sanan, Malang. Proceeding Seminar Nasional Pascasarjana IV, 24 Agustus 2004. Program Pascasarjana Institut Teknologi 10 November Surabaya.

Utomo, Rizon Pamardhi \& Kusumastuti. 2003. Kajian Tata Ruang Sistem Permukiman di Wilayah Kabupaten Sragen. Arsitektura, Vol.01, No.1, April 2003.

2002. International Research on Home Based Enterprises 2002 Indonesia-India-South AfricaBolivia. Laboratory For Housing And Human Settlement Architecture-ITS.

\section{Buku dan Literatur lain}

Budiharjo, Eko. 1997. Arsitektur dan Kota di Indonesia. Penerbit PT. Alumni Bandung. Bandung. Handinoto \& Soehargo, Paulus H. 1996. Perkembangan Kota dan Arsitektur Kolonial Belanda di Malang. Lembaga Penelitian dan Pengabdian Kepada Masyarakat Universitas Kristen Petra Surabaya. Penerbit Andi Yogyakarta.

Hasan, M Iqbal. 2002. Pokok-Pokok Materi Metodologi Penelitian dan Aplikasinya. Penerbit Ghalia Indonesia. Ciawi-Bogor Selatan.

Lang, J. 1987. Creating Architectural Theory: The Role of Behavioral Sciences in Environment Design. New York.

Laquian, A. Aprodicio. 1993. Basic Housing: Policy for Urban Sites, Services, and Shelter in Developing Countries. IDRC-208e.

Murison, H S \& J P, Lea. 1979. Housing in Third World Countries. Perspective on Policy and Practice. University of Sydney.

Nurdin, 1983. Perubahan Nilai-Nilai di Indonesia. Penerbit PT. Alumni Bandung. Bandung.

Rapoport, Amos. 1969. House Form and Culture. University of Wisconsin, Milwaukee. Prentice Hall, Inc., Englewood Cliffs, N. J.

Sardjono, Agung Budi. 2005. Menyiasati Ruang Sempit. Penerbit Trubus Agriwidya. Ungaran.

Schulz, Christian Norberg. 1985. The Concept of Dwelling. On The Way to Figurative Architecture. Rizzoli International Publications, Inc.

Soejono \& Abdurrahman. 1999. Metode Penelitian. Suatu Pemikiran dan Penerapan. Penerbit Rineka Cipta. Jakarta. 